\title{
Community Participation of Tourism Development in Galo Galo Island, Morotai, Maluku Utara Indonesia
}

\author{
Noviyanti Soleman ${ }^{1}$ and Viyouth Chamruspanth ${ }^{2}$
}

\begin{abstract}
Galo Galo Island is one of the islands in Morotai which has been proven that have the best underwater life for diving in North Maluku, Indonesia. Morotai is one of the places that is being strongly promoted by the Ministry of Tourism through "10 new Bali" program because of its beautification and potentials, as tourism is one of the biggest foreign exchange income of Indonesia. The very famous tourist assets of Galo Galo Island Morotai include white sand beaches and marine resources for diving spot. Even the beauty is can attract international parties to come such as USAID with conservation ecosystem. Based on existing data, galo galo is one of the places with the most visitors in Morotai. As one of the country's promotion priorities, Morotai and Galo Galo have the opportunity to bring large income for the country and local community. This paper aims to find out how the participation of local people in managing tourism assets of Galo Galo Island, while the assets is potentially to boast income. To answer the research question, the author uses the concept of Community Based Tourism by Goodwin and Santili. The research is using qualitative approach supported by primary and secondary data.
\end{abstract}

Keywords - Community based tourism, Community participation, Morotai Island, Tourism.

\section{INTRODUCTION}

\section{A. Background of Study}

Galo galo is one of the 33 islands that located in Morotai district, North Maluku, Indonesia. Galo galo island involve into sub-district of southern Morotai. Galo galo island is placed exactly in the south part of Morotai main island, take less or more 45 minutes by the main island. The island have 15.000 M2 of total area (KEBTKE, 2019) with the total population 616 people. The ratio between male and female about $330: 286$, meanwhile the total household is about 126.

Morotai is famous with the tourism assets. As this year, Morotai is promoted by the Ministry of Tourism Indonesia with the program 10 new bali. The 10 new bali is a program that assign ten places of tourist destination that has been prioritized in promote by the ministry of tourism. Those 10 new bali potentially have beautification that can attract people to come, whereas its classified into three which are authority

Noviyanti Soleman S.IP (Bach of Political Science), Khon Kaen University, Thailand.

Asst. Prof. Viyouth Chamruspanth Ph.D, Khon Kaen University, Thailand body, national tourism strategic area, special economic zones of tourism.

About three classification of tourism priority, Morotai is included into special economic zones of tourism. In the President Decree number 02 Year 2011 Article 1 stated that the special economic zones is the zone located in Indonesia that has been assigned to organize the economic function and will get certain facilitation. Meanwhile in article 3 the special economic zones of tourism is use to have the activities that can support the entertainment and recreation, meeting, exhibition and another related activities. (PERATURAN PEMERINTAH REPUBLIK INDONESIA, 2011)

Morotai can be regarded as one of the districts that has a fairly high tourist attraction. Aside from being one of the special economic zones and national tourism priorities, Morotai holds evidence of the history of world war two. Which is Morotai once became the base of the USA in the second world war and also the hiding place of the general Nakamura (Japanese soldier). So that there is still a lot of evidence that the world war is stored in Morotai. This has become one of the potentials for Morotai to attract foreign tourists, especially USA and Japan, to come and visit. Thus the potential of other tourism destinations in Morotai to be visited becomes greater.

Based on existing data, galo galo is one of the places with the most visitors in Morotai. Even though there are a lot of tourism assets in Morotai, but the statistics data shows that the southern part of Morotai is the most popular for tourist. Here is the data of $2012-2014$ about the number of tourist.

TABLE I

NUMBER OF TOURIST

\begin{tabular}{|c|c|c|c|c|}
\hline No & Sub districts & $\mathbf{2 0 1 2}$ & $\mathbf{2 0 1 3}$ & $\mathbf{2 0 1 4}$ \\
\hline 1 & Morotai Selatan & 1000 & 630 & 574 \\
\hline 2 & Morotai Timur & 263 & 110 & 19 \\
\hline 3 & Morotai Utara & 266 & 86 & 126 \\
\hline 4 & Morselbar & 134 & 57 & 37 \\
\hline 5 & Morotai Jaya & 363 & 145 & 141 \\
\hline \multicolumn{2}{|}{ Tourists } & 2025 & 1028 & 897 \\
\hline
\end{tabular}

a. Source: (Badan Perencanaan Daerah Morotai, 2015)

So far, Morotai indeed very famous for the beauty of a group of island islands and fine white sand beaches. One of the well-known beach destinations to the international arena is Dodola Island. Over time, Morotai tourism is more explored and one of the destinations for tourists is Galo Galo Island. The very famous tourist assets of Galo Galo Island Morotai 
include white sand beaches and marine resources for diving spot (KITAMOROTAI2018, 2018).

Spot diving in dodola island become one of the favorites among 25 spots for the whole district. Underwater beauty such as the wealth of coral reefs and various species of fish is a special attraction for diving spots in Morotai. Not a few divers in Indonesia who are willing to come and enjoy the underwater beauty of Galo Galo. Coupled with all that is still very pure and awake or has not been touched by naughty hands. No wonder if it is able to invite divers in the Indonesian archipelago and even internationally to come and enjoy the underwater paradise.

Underwater beauty such as the wealth of coral reefs and various species of fish is a special attraction for diving spots in Morotai. Not a few divers in Indonesia who are willing to come and enjoy the underwater beauty of Galo Galo. Coupled with all that is still very pure and awake or has not been touched by naughty hands. No wonder if it is able to invite divers in the Indonesian archipelago and even internationally to come and enjoy the underwater paradise.

The beauty and wealth of the underwater island of galo galo was able to attract the attention of the world. Given that USA has an unforgettable history, now USA is strengthening the relationship by collaborating with the galo galo submarine. Not long ago the US ambassador to Indonesia took the time to attend and visit the galo galo island. Reporting from imalut.com news, the presence of the US ambassador to Indonesia to the galo galo island to undergo cooperative relations in the underwater conservative field.

The US Ambassador to Indonesia admits that he is amazed at the underwater beauty that is on the Galo-galo island and hopes that the local community will help maintain and preserve the beauty (i-malut, 2019). With the existence of a partnership on marine conservation, it is expected that local residents will be able to carry out sustainable tourism well so that it will be eternal and able to treat nature as it should. Besides that, the US embassy also did the human resource development such as teach English for the young generation, underwater photo and surfing (Yamin, 2019).

The explanation above clearly stated that actually Morotai especially galo galo has big opportunity for economic development. The profit is not just for the provincial or district economic development but will be impact to the national income. That is why Morotai has been set as the country's promotion priorities. There is possibilities shows by the tourism of Morotai that can really help the economic improvement either for the government or the local community.

\section{B. Research Question}

Based on the data that has been explained above which is the Galo Galo Island have big opportunity for tourism development that can be a profit for local community. So, how the local community involve or participate in the tourism development while it is can be a profit for their economic.

\section{C.Research Objectiv}

Regarding to the research question above, so that the paper aims to find out how the participation of local people in managing tourism assets of Galo Galo Island, while the assets is potentially to boast income.

\section{LITERATURE REVIEW}

\section{A. Previous study}

This study uses research with the title "Pengembangan Community Based Tourism Sebagai Strategi Pemberdayaan Ekonomi Masyarakat di Kabupaten Kulon Progo, Daerah Istimewa Yogyakarta - The development of community-based tourism as a strategy for community economic empowerment in Kulon Progo District, Special Region of Yogyakarta" as a reference and view in examining the object (Rahayu, Dewi, \& Fitriana, 2015). In that study CBT was used as a strategy to improve the economy of the local community, but the research in this paper was only limited to seeing the forms of community participation in managing their own tourism assets. Although in the end the economy has become one of the expected positive impact but the author does not focus on the economic impact and only looks at how the form of community efforts to participate in tourism development.

Reference research produced results that CBT was carried out in the form of social-culture tourism and eco-tourism. With a qualitative descriptive method, it is able to answer the research question. As this research is expected to be able to produce a form of community participation in tourism development.

\section{B. Concept of Community Based Tourism}

The concept of community based tourism is actually has been exist since long time ago. Even though some people is not really familiar with that term, but there are a lot of studies regarding to this concept around the world. The word community based tourism sometimes has been called as local tourism (Asker, Boronyak, Carrard, \& Paddon, 2010), rural tourism and eco-tourism. It is not a big deal, cause only the use of term while the meaning are still the same.

Some people might be ask why do people call it local tourism? Rural tourism? Or eco-tourism? The word local tourism instead of community based tourism is because how the local people manage or involve in their own tourism assets. Rural tourism because the community based tourism is about how the rural people or low economic development area that use the tourism to improve their economic. Eco-tourism means the tourism with environmental friendly tourism.

Goodwin and Santili mention that community based tourism is the tourism of the local people, that has been managed directly by the local community and absolutely have great benefits for them (Goodwin \& Santilli, 2009). So that the community based tourism is from, by and for local community. Here we can see that Goodwin and Santili tries to explain about how the important things of local people participation in manage the tourism because it will be back to them or give 
profit to them.

There are 10 principles of community based tourism that impacted to the community development such as: 1 . Recognize, support and promote community ownership of tourism; 2. Involve community members from the start in every aspect; 3 . Promote community pride; 4. Improve the quality of life; 5. Ensure environmental sustainability; 6 . Preserve the unique character and culture of the local area; 7. Foster cross-cultural learning; 8. Respect cultural differences and human dignity; 9. Distribute benefits fairly among community members; and 10 . Contribute a fixed percentage of income to community projects. (Suansri, 2003)

From what that has been mentioned by Suansri, we can conclude that community based tourism is about how the local people involve in every single step of tourism development whether in promote and organize, how they can introduce what they have for the tourist either accept what outsider have in order to build the cultural exchange, how they can protect their environment for the sustainability and exactly about the profit that they can gain.

\section{MeTHODOLOGY}

Qualitative method is chosen by the author to complete this research. While this study is directly discuss about community participation so that the qualitative approach is more accurate to use in answering the research question. The qualitative study is more interested in achieving authenticity or about the fair, honest and social life of the community in daily life than realizing a single version of "Truth" (Neuman, 2014). To complete the qualitative research, the author will use primary data such as direct observation and interview. Then also about the secondary such as books, news, report and other data related to the topic.

\section{RESULTS \& FINDINGS}

To analyze the existing forms of public participation in tourism, especially when we have to know what tourism assets are owned by Galo Galo Island. This is to facilitate the classification of community participation in the development of tourism itself. In addition to tourism assets, the event related to tourism marketing is one of the important factors, as the more successful the event is, the more tourists who come and the development of supporting infrastructure will be influent.

\section{A. Asset of tourism in galo galo island}

- White sand beach

As previously explained, galo galo is very famous for its white sand beach. Even though Morotai district has very much even almost all covered by white sand, what Galo Galo has is one of the best. This has been proven by various reviews of tourists who came to visit. the texture of the sand is smoother and softer coupled with the bright color makes it a beauty in itself and distinguishes galo galo island white sand with other beaches.

\section{- Diving spot}

Diving spots are also one of the reasons why tourists visit the galo galo island. Galo galo diving spots are very well known, several times national television broadcasts covered the underwater beauty of the galo galo island and international actors such as the US consulate held conservation to help safeguard the underwater paradise. on galo galo diving spots, tourists will be presented with the beauty of coral reefs, various kinds of colorful ornamental fish that spoil the eyes, if lucky even sometimes will meet sharks and stingrays, as for seaweed and sea urchins which are also very easily found on the spot galo galo island diving. Diving spots are one of the concentrations that are being promoted by the government and local people.

\section{- Mangrove}

Mangrove is one program that has recently been intensively carried out on Galo Galo Island. as it is known that mangroves can help prevent abrasion, with small island conditions like galo galo, abrasion prevention is very useful. Mangrove planting is also very good for breeding and preservation of marine life. on the other hand mangroves add to the natural beauty of the galo galo island, so it is very suitable to be used as a photo spot for those who come to travel.

- Sunset and Sunrise Spot

As is the geographical condition of the galo galo island, which is surrounded by a group of other small island islands, without the mountains making the galo galo island one of the right places to enjoy the sunrise and sunset.

\section{- Surfing}

Although galo galo island does not promise big waves for surfing, not a few people enjoy surfing at galo galo. The waves are not too big because the condition of the galo galo island surrounded by other islands makes this island the right place to surf, especially for beginners. However, based on existing data, the local younger generation received surfing training so that it would not be possible in the future to surf as one of the galo galo tourism selling points.

- Infrastructure

Among the asset assets above, it would be less satisfying if it is not supported by good infrastructure. Although it is not too advanced in infrastructure, some basic infrastructure already exists on Galo Galo Island. among them are bridges as speed boat ports, entrance gates to welcome tourists, galo galo icon names that become markers from a distance, directions signs, public toilets, and bench to relax enjoying the beauty of the beach.

\section{B. Event tourism promotion of Galo Galo island}

\section{- Wonderful Galo Galo}

Wonderful galo galo is one of the galo galo tourism promotion events with the aim of inviting tourists to come to galo galo island. This event was held by KKAD University students in KKN in collaboration with the Morotai District Tourism Office. This activity is quite successful because it can attract public attention. The activity held in 2018 presents events titled culture and the uniqueness of local customs. 


\section{Tourism industry}

\section{- Diving guide}

Because diving spots are one of the tourism assets owned by galo galo island, one of the tourism industries being developed is a diving guide. although not many, some galo galo island teenagers have been trained to become diving guides. With the skills they have, they have now been able to become guides to take guests to diving spots and see the underwater beauty they have. Although they already have several people who are involved in diving guides, until now diving training is still being carried out as a form of human resources development.

\section{- Salted fish seller}

Galo galo island is one of the islands with a number of fishermen around $90 \%$. with a number that is very much spelled out, of course the resulting marine products are not small. One of the tourism industries owned by galo galo people is salted fish products.

\section{- Koblisuda}

KOBLISUDA is one of the typical souvenir products produced by local community groups. the products sold are local handicrafts. various products made from bamboo such as woven and soap from natural ingredients become souvenirs for tourists who come to visit.

\section{- Tour guide (Code of conduct)}

Besides having a diving guide, it turned out that local residents had also been trained as tour guides. Interestingly, being a tour guide was a local youth. Besides being trained, they are also provided with a code of conduct which provides guidance and a reference for them not being a tourist guide.

- Small Shop

Like other tourist attractions, at galo galo there is also a small shop that sells various foods and basic needs for tourists. This small shop can be found around spot tourism. this is certainly very easy for tourists who come and visit if they need it.

\section{DISCUSSION}

As Goodwin and Santili mentioned that community based tourism is the tourism of the local people, that has been managed directly by the local community and absolutely have great benefits for them. Based on the data in findings we can see that actually the tourism of the local people is reverse to the tourism asset and the tourism industry is reverse to community participation in manage the tourism assets.

The community based tourism of Goodwin and Santili is the tourism of the local people. It is means that the tourism in owned by the local people. In galo galo island the tourism assets is located in that island means the people in that island have right of that as the public place. They are white sand beach, diving spot, mangrove, sunset and Sunrise Spot, surfing and supported with public service such as infrastructure.

From the tourism industry we can see that the community participation is quite high. The first thing is about their enthusiasm, while the young generation is active participate for guide training so that they can be the tour guide and diving guide. Even though the training is from outsider such as US consular, the young generation still active to join. As we know that US consular come and doing human resource development in form of teaching English, teaching surfing and training about underwater conservation.

Second thing is about the form of group. Not just join the training, community there also excited in form the group. There are several group of tourism such as souvenir group "koblisuda", salted fish group, tour guide group, diving guide group, etc. The third is about the participation in promoting the tourism. The promotion now is going to social media such as official account of facebook and Instagram. It is one of the best way to promote the people to come as the social media have no limit of time or space so people around the world can see the beauty of galo galo island.

Last is participation in support the tourist need such as shop for the tourist. This is very important because the visitors will not be difficult to fulfill their needs when they were there

\section{CONCLUSSION}

In conclusion the level of community participation or community based tourism on the galo galo island is quite high. Although not as good as the tourist attraction like Bali, but as a starting point is a pretty good value. With a small population and community participation in many forms it can be said that the majority of people participate in tourism development.

With a very good level of participation, it is expected that the social and economic conditions of the local community can experience good progress. So that the community feels directly the results of their hard work.

\section{REFERENCES}

[1] Asker, S., Boronyak, L., Carrard, N., \& Paddon, M. (2010). Effective Community Based Tourism: A Best Practice Manual. Sydney: Sustainable Tourism Cooperative Research Centre.

[2] Badan Perencanaan Daerah Morotai. (2015, November). Profil Daerah Kabupaten Pulau Morotai. Retrieved from Bappeda Pulau Morotau: http://bappeda.pulaumorotaikab.go.id/gambar/download/upload/downlo ad-15-profil-daerah-kabupaten-pulau-morotai-2015.pdf

[3] Goodwin, H., \& Santilli, R. (2009). Community-Based Toursim: a success. ICRT Occasional Paper 11.

[4] i-malut. (2019, April 3). Dubes Amerika Terpesona Dengan Keindahan Bawah Laut Galo-Galo, Morotai - Ambassador of USA Fallin in Love with Galo Galo Underwater. Retrieved from imalut Indonesia: https://imalut.com

[5] KEBTKE, E. P. (Director). (2019). Survey Energi Surya di Pulau Galo Galo Morotai [Motion Picture].

[6] KITAMOROTAI2018 (Director). (2018). Sebuah Cerita yang (belum) usai II KKN-PPM UGM 2018 Morotai - A Story That Is Not Over Yet (eng) [Motion Picture].

[7] Neuman, W. L. (2014). Social Research Methods (7th ed.). Edinburgh: Pearson Education Limited.

[8] Peraturan Pemerintah Republik Indonesia. (2011). Peraturan Pemerintah Republik Indonesia Nomor 2 Tahun 2011 Tentang Penyelenggaraan Kawasan Ekonomi Khusus. Indonesia.

[9] Rahayu, S., Dewi, U., \& Fitriana, K. N. (2015, April). Pengembangan Community Based Tourism di Kabupaten Kulon Progo Daerah Istimewa Yogyakarta. Retrieved from Universitas Negeri Yogyakarta: https://eprints.uny.ac.id

[10] Suansri, P. (2003). Community Based Tourism Handbook. Thailand: Responsible Ecological Social Tour-REST.

[11] Yamin, F. (2019, April 7). Anak-anak Pulau Morotai Diajar Berselancar, Berbahasa Inggris dan Menjaga Laut. Retrieved from KOMPAS: http://regional.kompas.com 